\title{
The effect of bioactive components of plant origin on the physicochemical and sensory characteristics of functional sausages
}

\author{
Andrzej PÓŁTORAK ${ }^{1}$, Monika MARCINKOWSKA-LESIAK ${ }^{1 *}$, Krzysztof LENDZION ${ }^{1}$, Anna ONOPIUK ${ }^{1}$, \\ Małgorzata MOCZKOWSKA ${ }^{1}$, Iwona WOJTASIK-KALINOWSKA ${ }^{1}$, Agnieszka WIERZBICKA ${ }^{1}$
}

\begin{abstract}
The aim of this study was to determine the effect of bioactive compounds of natural origin on the quality of sausages. Four variants of sausages were manufactured: a control variant $(\mathrm{C})$ and three variants with the addition of catuaba, galangal, roseroot, maca, guarana and polyfloral honey $\left(\mathrm{E}_{1}, \mathrm{E}_{2}, \mathrm{E}_{3}\right)$. The $\mathrm{pH}$ values, colour and chemical parameters (total phenolic content, total antioxidant activity and anti-inflamantory activity) of the meat batters and finished products were determined. Additionally, texture and sensory analyses of the sausages were performed. It was found that regardless of slightly lower acceptability, sausages with bioactive components were characterised by increased antioxidant properties, higher total phenol values and higher anti-inflamantory activity. The best results were obtained when the highest level of bioactive compounds was used (1.734\% of catuaba bark, $0.022 \%$ of ground great galangal root, $0.458 \%$ of ground roseroot, $0.614 \%$ of maca root extract (4:1), $0.600 \%$ of ground guarana and $1.146 \%$ of polyfloral honey).
\end{abstract}

Keywords: functional foods; sausages; natural components; bioactive component.

Practical Application: Functional sausages for consumption.

\section{Introduction}

Due to the natural aging process, the production of androgens decreases with age. The fall in testosterone production in men ranges from $1 \%$ to $2 \%$ per year (Feldman et al., 2002). This process affects the reduction of bone mineral density, structure composition, syndrome stiffness, metabolism, diabetes and cardiovascular diseases (Gomuła \& Rabijewski, 2010; Huhtaniemi, 2014; Mouser et al., 2016). Studies have shown that low levels of androgens are associated with symptoms of fatigue, irritability, dyspnea, vigorous decline, low vigour, lack of physical strength and sexual dysfunction in men (Barrett-Connor et al., 1999; Giltay et al., 2012; Rhoden \& Morgentaler, 2004; Wang et al., 2009). Low levels of androgens also increase the risk of symptoms of depression (Ford et al., 2016; McHenry et al., 2014; Westley et al., 2015). The elimination of the negative symptoms associated with a decrease in androgen production may be addressed by components naturally occurring in foods and herbs with proven health-promoting and stimulating properties.

A plant with documented pro-health characteristics, particularly suitable for the elderly struggling with the decline of androgen production is Catuaba (Trichilia catigua). Extracts from the catuaba cortex are used in diseases related to oxidative stress, and also as a neurostimulant, anti-neuritic and aphrodisiac agent (Campos et al., 2005; Chassot et al., 2011; Kamdem et al., 2013). Additionally, catuaba is characterised by its analgesic (Viana et al., 2011), antimicrobial (Pizzolatti et al., 2002), antioxidant (Brighente et al., 2007; Chassot et al., 2011; Tang et al., 2007) and anti-inflammatory (Barbosa et al., 2004) properties.

Another well-known plant with adaptogenic properties that increase the body's immunity and allow it to cope with all sorts of stressful situations (Wal \& Wal, 2013) is roseroot (Rhodiola rosea). Its most active ingredient, which has the chemical structure of phenolic glycosides is salicylic acid (Cao et al., 2006; Chen et al., 2008). Roseroot contains, among others, proanthocyanidins, flavonoids, glycosides, organic acids and essential oils (Majewska et al., 2006; Wal \& Wal, 2013).

The health properties of the maca root (Lepidium meyenii) have also been documented. For example, maca improves sexual function, counteracts the symptoms of menopause (Lee et al., 2016) and has a beneficial effect on spermatogenesis (Melnikovova et al., 2015). Studies have also demonstrated its neuroprotective effect (Pino-Figueroa et al., 2010). Tang et al. (2017) indicate that polysaccharides isolated from the maca root may be considered in the future as a functional food ingredient limiting fatigue.

Also galangal (Alpinia galanga) contains many bioactive compounds such essential oils, tannins, glycosides, phenolic compounds and diterpenes. There are 387 different activities of this plant (Ravindran et al., 2012). A lot of physiological function of this plant have been reported (Ravindran et al., 
2012). For example galangin (3,5,7-trihydroxyflavone), a flavonoid contained in the galgan, has an antineoplastic effect (Quadri et al., 2000). A very important function of galangin is also the aromatase inhibition that prevents the conversion of testosterone to estrogens (Heo et al., 2001).

Further, guarana (Paullinia cupana, Sapindaceae) is not only a source of caffeine, but also contains many other active compounds such as catechine, choline, adenine, hypoxanthine, theophylline, saponins, theobromine and essential oils. It affects positively the wellbeing of people in depression, strengthens the body's resistance to stress, and also soothes migraines. In addition, guarana has strong antioxidant and antimicrobial properties; thus, it can protect against the growth of food-spoiling bacteria and fungi (Basile et al., 2005; Majhenič et al., 2007).

A food ingredient of proven bioactive action is honey. It exhibits antioxidant, anti-inflammatory, anti-cancer, antihyperlipidemic, cardioprotective activity and is useful in the treatment of eye diseases, the digestive system, neurological disorders, fertility disorders and wound healing (Meo et al., 2017; Oryan et al., 2016; Rao et al., 2016; Rashad et al., 2009). It has also been shown that honey has a beneficial effect on the levels of follicle-stimulating hormone (FSH) and luteinising hormone (LH) responsible for testosterone production (Kenani et al., 2015; Rajabzadeh et al., 2015).

Recently, there has been an increased interest in functional food, exhibiting pro-health properties among different consumer groups. Sausages with natural bioactive components fall within this trend (Bhat \& Bhat, 2011). The purpose of the research was to examine the influence of bioactive components, such as catuaba, galangal, roseroot, maca root, guarana and polyfloral honey on the quality and sensory characteristics of functional sausages.

\section{Materials and methods}

\subsection{Material and reagents}

Pork ham, pork shoulder, pork chuck, pork back fat and beef shin shank were obtained from a regional distributor (EMEAT JSC, Łuków, Poland), while all non-meat ingredients were delivered from the local market: ground black pepper, dried marjoram, garlic, ground lovage root and ground allspice from PRYMAT Ltd (Poland), bear's garlic from Dary Natury Co. (Poland), catuaba bark and ground grater galangal root from Nanga Co. (Poland), ground roseroot, maca root extract 4:1 and ground guarana from Młyn Oliwski Ltd, (Poland) and polyfloral honey was collected from the village of Kaborno (Poland). All chemicals and reagents used were of analytical grade and were procured from Sigma-Aldrich (St. Louis, MO, USA).

\subsection{Product formulation and processing}

At first, boneless meat and fat was cut into cubes measuring $3 \mathrm{~cm} \times 3 \mathrm{~cm} \times 3 \mathrm{~cm}$ and dry cured with a mixture of salt and nitrine (2\%) for 4 days at $3-4^{\circ} \mathrm{C}$. The raw material composition of the analysed sausages is indicated in Table 1 . The standard spice blend contained $25.18 \%$ of ground black pepper, $7.32 \%$ of dried marjoram, $26.35 \%$ of fresh garlic, $7.47 \%$ of bear's garlic, $20.50 \%$ of dried garlic, $5.86 \%$ of ground lovage root and $7.32 \%$ of ground allspice.

Cured meat and fat were ground in a grinder (ZELMER 687.5 , Poland) with a $16 \mathrm{~mm}$ (pork ham), $8 \mathrm{~mm}$ (pork shoulder and pork chuck), $2 \mathrm{~mm}$ (pork back fat and beef shin shank) diameter of mincing plate. Then beef shin shank was mixed in a Multi-Function All-in-One Cooker (Speedcook, RPOL, Mielec, Poland) with standard spice blend and ice (control group), or in the case of other groups with standard spice blend, polyfloral honey, ground greater galangal root, ground roseroot, maca root extract, ground guarana and frozen catuaba decoction (prior to the process, catuaba bark was cooked for 10 minutes, strained, cooled and frozen) in the proportions indicated in Table 1. Subsequently, the remaining meat and back fat were added and mixed manually. The resulting batters were stuffed into natural casings from sheep $(22-24 \mathrm{~mm})$ using a batch-wise stuffing machine (MR13, Oscar Cooks, Austria). Then, the sausages were set for 5 hours at $8-10^{\circ} \mathrm{C}$, air dried for 1.5 hours at $25-30{ }^{\circ} \mathrm{C}$, warm smoked (60\% alder, $20 \%$ beech, $20 \%$ cherry of wood chips) for 2 hours (1 hour at $40-50{ }^{\circ} \mathrm{C}$ and 1 hour at $50-60^{\circ} \mathrm{C}$ ) in a traditional smokehouse with a

Table 1. Raw material composition of analyzed sausages.

\begin{tabular}{|c|c|c|c|c|c|}
\hline \multirow{2}{*}{\multicolumn{2}{|c|}{ INGREDIENTS }} & \multicolumn{4}{|c|}{ GROUP } \\
\hline & & $\mathrm{C}^{1}$ & $\mathrm{E}_{1}$ & $\mathrm{E}_{2}$ & $\mathrm{E}_{3}$ \\
\hline \multirow{5}{*}{$\begin{array}{l}\text { CURED MEAT AND } \\
\text { FAT MIXTURE } \\
(\Sigma 100 \%)\end{array}$} & pork ham & 42.850 & 42.850 & 42.850 & 42.850 \\
\hline & pork shoulder & 12.790 & 12.790 & 12.790 & 12.790 \\
\hline & pork chuck & 18.410 & 18.410 & 18.410 & 18.410 \\
\hline & pork backfat & 11.650 & 11.650 & 11.650 & 11.650 \\
\hline & beef shin-shank & 14.300 & 14.300 & 14.300 & 14.300 \\
\hline \multirow{5}{*}{$\begin{array}{c}\text { BIOACTIVE } \\
\text { COMPONENTS } \\
(\%)^{2}\end{array}$} & catuaba bark used for decoction & - & 0.867 & 1.301 & 1.734 \\
\hline & ground greater galangal root & - & 0.011 & 0.017 & 0.022 \\
\hline & ground roseroot & - & 0.229 & 0.344 & 0.458 \\
\hline & maca root extract $(4: 1)$ & - & 0.307 & 0.461 & 0.614 \\
\hline & ground guarana & - & 0.300 & 0.450 & 0.600 \\
\hline
\end{tabular}

${ }^{1} \mathrm{C}$ - control group; $\mathrm{E}_{1}, \mathrm{E}_{2}, \mathrm{E}_{3}$ - groups, where bioactive components were used $\left(\mathrm{E}_{2}=1.5 \times \mathrm{E}_{1}, \mathrm{E}_{3}=2 \times \mathrm{E}_{1}\right) ;{ }^{2} \mathrm{Quantity}$ in relation to cured meat and fat mixture (100\%). 
generator (Dymbox, Poland). Following that, the sausages were steamed in a convection oven at $71-73^{\circ} \mathrm{C}$ to obtain an internal temperature of $68^{\circ} \mathrm{C}$ (CPE 110, Küppersbuch, Germany) and cooled in air for 1 hour at about $10^{\circ} \mathrm{C}$. Ultimately, the obtained meat products were vacuum-packed in LD-PE bags, using a vacuum-packaging machine (VAC-20 SL 2A, Edesa, Spain). The physicochemical and consumer evaluation were carried out 24 hours after production. Each sausages group was produced in three separate trials.

\subsection{Physico-chemical analysis of sausages}

\section{pH determination}

The $\mathrm{pH}$ value of sausages was measured according to the ISO 2917:2001/Ap1:2002 standard (ISO, 2002), using a pH-meter equipped with a glass electrode (Testo 205, Testo Inc., Lenzkirch, Germany). After calibration against buffers of $\mathrm{pH} 4.0$ and 7.0, measurement was conducted (an electrode was inserted to a depth of $2 \mathrm{~cm}$ directly into the samples, the temperature of the samples during measurements was $2 \pm 1{ }^{\circ} \mathrm{C}$ ). Analysis of each group was carried out in triplicate.

\section{Instrumental colour measurement}

The instrumental measurement of the colour parameters of sausages was determined using a Minolta chromameter (CR-400, Konica Minolta Inc., Tokyo, Japan), with a spot diameter of $8 \mathrm{~mm}, \mathrm{a} \mathrm{D}_{65}$ illuminant and an observer angle of $2^{\circ}$. Lightness $\left(\mathrm{L}^{\star}\right)$, redness $\left(\mathrm{a}^{\star}\right)$ and yellowness $\left(\mathrm{b}^{\star}\right)$ were recorded on the CIE LAB colour space system. Before measurement, the chromameter was calibrated using the white standard calibration plate late $\left(L^{*}=98.45, a^{*}=-0.10, b^{*}=-0.13\right)$. Measurements of the samples were taken from five locations including the centre and every quarter of the sample. At least 10 measurements were recorded from each sample. Additionally, the hue angle (tonality) and saturation index (vivacity) were estimated and determined according to the following formulas (Artés et al., 2002) (Equations 1 and 2):

hue angle $=\operatorname{arctg}\left(b^{*} / a^{*}\right)$

saturation index $=\left(a^{*^{2}}+b^{*^{2}}\right)^{1 / 2}$

\section{Texture Profile Analysis (TPA)}

Texture profile analysis (TPA) was carried out using the Instron 5965 Universal Testing Machine (Instron, Norwood, MA, USA). For the compression of uniform disks of sausages' slices, a flat, $4 \mathrm{~cm}$ diameter cylinder probe was used. Samples measuring $18 \mathrm{~mm}$ in height and $18 \mathrm{~mm}$ in diameter were double compressed to the point of $50 \%$ reduction of their initial height with a relaxation time of $5 \mathrm{~s}$ (cell capacity $-500 \mathrm{~N}$; head speed $-2 \mathrm{~mm} / \mathrm{min}$.). Based on the force versus time curve, hardness $\left(\mathrm{N} / \mathrm{cm}^{2}\right)$, springiness $(-)$, cohesiveness $\left(\mathrm{J} / \mathrm{cm}^{2}\right)$ and chewiness $(\mathrm{N})$ were determined. The measurement was conducted in three repetitions for each sample.

\section{Proximate Composition Analysis}

The determination of moisture, fat and protein content was performed in the spectral range of 780-2500 nm, using a near-infrared spectrometer (NIR Flex N-500, Büchi Labortechnik AG, Flawil, Switzerland). Portions of meat batters or homogenized sausages weighing about $150 \mathrm{~g}$ were placed on a glass Petri dish at a depth of $0.5 \mathrm{~cm}$. The measurement was conducted in three repetitions for each sample using a NIRFlex Solids module of spectral range $12.500-4.000 \mathrm{~cm}^{-1}$ in reflectance mode with a resolution of $8 \mathrm{~cm}^{-1}$ (Wyrwisz et al., 2012).

\section{Determination of phenolic compounds}

The total phenolic content (TPC) of batters and sausages was measured by the method described by Singleton \& Rossi (1965) with some modifications. For this purpose $2.5 \mathrm{~g}$ of sausage from each group was homogenized with $7.5 \mathrm{ml}$ of ethanol for $120 \mathrm{~s}$ at $12 \mathrm{rpm} \times 1000$ (Ultra Turrax homogeniser, T18 basic, IKA Werke, Staufen, Germany). Then to $0.1 \mathrm{~mL}$ of obtained extracts $6.0 \mathrm{ml}$ of distilled water and $0.5 \mathrm{~mL}$ of Folin-Ciocalteu reagent were added and mixed thoroughly. After $3 \mathrm{~min} ., 1.5 \mathrm{ml}$ of sodium carbonate of $200 \mathrm{mg} / \mathrm{mL}$ concentration was added to reactive mixtures, which were finally adjusted with water to $10 \mathrm{~mL}$ and stored for $30 \mathrm{~min}$ in a water bath (WNB 7, Memmert, Schwabach, Germany) in the temperature of $40^{\circ} \mathrm{C}$. Absorbance was measured spectrophotometrically at a wavelength of $765 \mathrm{~nm}$ (SparkTM 10M, Tecan Group Ltd, Männedorf, Switzerland). Gallic acid solutions $(0 \mathrm{mg} / \mathrm{mL}, 0.2 \mathrm{mg} / \mathrm{mL}, 0.3 \mathrm{mg} / \mathrm{mL}$, $0.4 \mathrm{mg} / \mathrm{mL}, 0.5 \mathrm{mg} / \mathrm{mL}$ ) were used to prepare a calibration curve. The concentration of total phenolic content in the sausages was expressed as gallic acid equivalents (GAE) in $\mathrm{mg}$ per $100 \mathrm{~g}$ of sample (mg of GAE/100 g). All measurements were performed in three replications.

\section{$D P P H$ radical scavenging activity}

DPPH (1, 1-diphenyl-2-picrylhydrazyl) free radical scavenging activity of batters and sausages was determined spectrophotometrically according to a modified method described by Sánchez-Moreno et al. (1998). For this purpose, $2.5 \mathrm{~g}$ of samples from each group were homogenized with $7.5 \mathrm{ml}$ of ethanol for $120 \mathrm{~s}$ at $12 \mathrm{rpm} x 1000$ (Ultra Turrax homogeniser, T18 basic, IKA Werke, Staufen, Germany), extracted at room temperature for $10 \mathrm{~min}$ on a rotary shaker (MyLab SLRM-3, NanoEnTek Inc., Korea) and then centrifuged at $1800 \mathrm{rpm}$ for $10 \mathrm{~min}$ (MPW Med. Instruments, Poland). Ultimately, the ethanolic extracts located above the sediments were collected. Next, $3.5 \mathrm{~mL}$ of $0.1 \mathrm{mM}$ DPPH ethanolic solution was added to $0.5 \mathrm{~mL}$ of obtained extracts, vortexed thoroughly and left in the dark at $25^{\circ} \mathrm{C}$ for $20 \mathrm{~min}$. Absorbance was measured spectrophotometrically at a wavelength of $517 \mathrm{~nm}$ (SparkTM 10M, Tecan Group Ltd, Männedorf, Switzerland). Ethanol was used as blank and all measurements were performed in three replications. The total antioxidant activity (TAA) expressed as \% reduction of DPPH was calculated as (Sánchez-Moreno et al., 1998) (Equation 3):

$\operatorname{TAA}(\%)=\left(1-A_{s} / A_{c}\right) \times 100$ 
where $A_{s}$ is the absorbance of the test sample and $A_{c}$ is the absorbance of the control (containing all the reagents except extract).

\section{Anti-inflammatory compounds}

The anti-inflammatory activity of batters and sausages based in the mechanism of the Morgan-Elson reaction was evaluated by modification of the method described by Osés et al. (2016). $5 \mathrm{~g}$ of samples from each group were homogenized (Ultra Turrax homogeniser, T18 basic, IKA Werke, Staufen, Germany) with $10 \mathrm{ml} \mathrm{50 \%} \mathrm{ethanol} \mathrm{solution} \mathrm{in} \mathrm{water.} \mathrm{Then,} 70 \mu \mathrm{l} \mathrm{of} 5 \mathrm{mg} / \mathrm{ml}$ hyaluronic acid sodium salt from Streptococcus equi and $100 \mu \mathrm{l}$ of buffer $(0.2 \mathrm{M}$ sodium formate, $0.1 \mathrm{M}$ sodium chloride and $0.2 \mathrm{mg} / \mathrm{mL}$ bovine serum albumin, $\mathrm{pH}$ adjusted to 3.68 with formic acid) were added to $200 \mu \mathrm{l}$ of samples. Then, mixtures were mixed gently and heated at $37^{\circ} \mathrm{C}$ for $10 \mathrm{~min}$ (water bath, WNB 7, Memmert, Schwabach, Germany). Next, $50 \mu \mathrm{l}$ of hyaluronidase from bovine testes type IV-S $(600 \mathrm{U} / \mathrm{mL})$ prepared in $0.9 \%$ sodium chloride was added and incubated 1 hour at the same conditions. $100 \mu \mathrm{l}$ of $0.8 \mathrm{M}$ potassium tetraborate was used to stop the enzymatic reaction. After a $3 \mathrm{~min}$ incubation in a water bath (WNB 7, Memmert, Schwabach, Germany), samples were cooled to room temperature. Ultimately, $750 \mu \mathrm{l}$ of dimethylaminobenzaldehyde (DMAB) solution were added ( $2 \mathrm{~g}$ of DMAB were added to $2.5 \mathrm{~mL}$ of $10 \mathrm{~N}$ hydrochloric acid and $17.5 \mathrm{ml}$ of glacial acetic acid, and then a $50 \%$ solution with glacial acetic acid was prepared). Absorbance of samples was measured spectrophotometrically at a wavelength of $586 \mathrm{~nm}$ (SparkTM 10M, Tecan Group Ltd, Männedorf, Switzerland) after a 20 min incubation (water bath, $37^{\circ} \mathrm{C}$ ). Buffer was used as blank and $\mathrm{N}$-acetyl-d-glucosamine standard solutions were used as standard for calibration curves. All measurements were performed in three replications. 1 unit (U) of hyaluronidase activity catalyses the release of $1 \mu \mathrm{mol} \mathrm{N}$-acetyl-d-glucosamine (NAG) per min under specified conditions. The percentage of enzyme inhibition was calculated as (Osés, et al., 2016):

$I=(1-Y / X) \times 100$

where I (\%) - percentage of inhibition, $\mathrm{X}-\mu \mathrm{mol}$ of NAG in the control sample and $\mathrm{Y}-\mu \mathrm{mol}$ of NAG of each sample reaction.

\subsection{Consumer evaluation of sausages}

The acceptability of the sausages was evaluated by 45 consumers (45 men ranging in age from 25 to 69 years) in standard conditions, including room temperature, individual booths and light of approximately $500 \mathrm{~lx}$. Samples with dimensions $18 \times 50 \mathrm{~mm}$ were presented to the consumers randomly and codified with four random numbers. Consumer were asked to express their opinion by placing a vertical line on the $10 \mathrm{~cm}$ unstructured line scales with defined border values. Nine sensory attributes were evaluated: colour (undesirable - desirable), odour (undesirable - desirable), taste (undesirable - desirable), foreign odour (imperceptible - perceptible), foreign taste (imperceptible perceptible), juiciness (dry - juicy), consistency (undesirable - desirable), fat perceptibility (imperceptible - perceptible) and overall acceptability (undesirable - desirable). Tea without sugar was served between tastings to purge the palate of sample residues. Consumer evaluation was undertaken in three sessions and a complete block design was used, where each consumer assessed all groups in each session.

\subsection{Statistical analysis}

All data were analysed statistically by analysis of variance (One-Way ANOVA) using the Statistica software version 12.5 (StatSoft Inc., Tulsa, USA). The differences between groups were tested according to Tukey's test, performed at the significant level of $\mathrm{p}<0.05$. The results in the tables are presented as mean values and standard deviations (SD). Furthermore, the relation between total phenolic content (TPC) and total antioxidant activity (TAA) was evaluated using Pearson's linear correlation at $\mathrm{p}<0.05$.

\section{Results and discussion}

\subsection{Physicochemical properties}

The addition of different levels of bioactive components of plant origin did not have any significant effect $(\mathrm{p} \geq 0.05)$ on $\mathrm{pH}$ values between all treatments (Table 2 ). These were in the range of 6.15-6.20 for meat batters and 5.82-5.88 for finished products.

Nevertheless, added ingredients significantly affected $(\mathrm{p}<0.05)$ colour parameters among experimental groups (Table 2$)$. Considering meat batters, as well as finished products, a decrease in $\mathrm{L}^{\star}$ values was observed along an increase in the addition of experimental components. Additionally, sausages batters from group $\mathrm{E}_{3}$ were characterised by significantly higher values of $\mathrm{a}^{*}$ and $\mathrm{b}^{*}$ parameters, as well as higher saturation index than other groups. All samples had a hue angle index around $1^{\circ}$ indicating their red colour. In the case of sausages, results demonstrated that only $\mathrm{a}^{*}$ values did not changed when experimental components were added (Table 1). Additionally, in the case of other color parameters, no significant ( $\mathrm{p} \geq 0.05)$ differences between sausages from $\mathrm{E}_{2}$ and $\mathrm{E}_{3}$ groups were observed. In general, fortified sausages were statistically darker $(\mathrm{p}<0.05)$ and their $b^{*}$ values, as well hue angle and saturation index, were more intense than those of the control group. Change in the colour parameters of products before and after thermal processing may be attributed to the colour of the used components and the amount in which they were added. The increase of sausage yellowness, however, is usually caused by lower antioxidative efficiency (Sebranek et al., 2005). In this case, it could be triggered by the presence of catechins in roseroot for example (Adamczyk et al., 2016; Wagh, et al., 2015).

The statistical analysis did not show significant differences ( $p>0.05$ ) in the textural properties of sausages with various levels of bioactive ingredients compared to the control group (Table 3 ).

Hardness, springiness, cohesiveness, adhesiveness, as well as, the chewiness values of samples were relatively constant, which may be related to the composition of the sausages. Additionally, no differences were observed ( $\mathrm{p} \geq 0.05$ ) for moisture, fat or protein among experimental groups, both in meat batters $(67.22 \% \pm 0.59$, $13.33 \% \pm 0.28$ and $15.44 \% \pm 0.35$, respectively) and final products $(59.02 \% \pm 0.62,17.63 \% \pm 0.24$ and $18.86 \% \pm 0.44$, respectively). The obtained results for basic composition were similar to the results generally reported for this kind of products and should not affect their physicochemical quality (Thomas et al., 2008). 
As shown in Table 4, it was found that the total phenolic content, total antioxidant activity and anti-inflamantory activity of examined groups showed considerable variations. All three analysed parameters were influenced by the level of bioactive ingredients addition $(\mathrm{p}<0.05)$.

It was observed that the total phenolic content (mg/100 g of f.w.) of the meat batters increased with bioactive components content. According to the control group, the amount of phenols doubled when the highest dose of components was used. Similar observations were noted for the finished products. This could be a result of the presence of polyphenols from galangal (Cheah
\& Abu-Hasim, 2000), maca (Sandoval et al., 2002), guarana (Basile et al., 2005), roseroot (Adamczyk et al., 2016) and honey (Pyrzynska \& Biesaga, 2009).

In this study, groups with bioactive components of plant origin, both before and after thermal processing, provided relatively high total antioxidant activity (above 76.85\% DPPH and 86.58\% DPPH respectively). The control group was characterised by the lowest total antioxidant activity (32.53\% DPPH for sausage batter and $46.88 \% \mathrm{DPPH}$ for the finished product). It is known that polyphenols in products of plant origin contribute to their potent antioxidant capacity (Rice-Evans et al., 1996). For example, the

Table 2. $\mathrm{pH}$ and color parameters of analyzed meat batters and sausages.

\begin{tabular}{|c|c|c|c|c|}
\hline \multirow{2}{*}{ PARAMETERS } & \multicolumn{4}{|c|}{ GROUP } \\
\hline & $\mathrm{C}^{1}$ & $\mathrm{E}_{1}$ & $\mathbf{E}_{2}$ & $\mathrm{E}_{3}$ \\
\hline \multicolumn{5}{|c|}{ SAUSAGE MEAT BATTERS } \\
\hline $\mathrm{pH}[-]$ & $6.19 \pm 0.02$ & $6.15 \pm 0.02$ & $6.17 \pm 0.03$ & $6.20 \pm 0.02$ \\
\hline$L^{*}[-]$ & $58.21^{\mathrm{c}} \pm 01.2$ & $57.90^{\mathrm{b}} \pm 1.26$ & $56.41^{\mathrm{ab}} \pm 1.90$ & $55.15^{\mathrm{a}} \pm 1.12$ \\
\hline$a^{*}[-]$ & $10.86^{\mathrm{a}} \pm 1.99$ & $10.53^{\mathrm{a}} \pm 1.15$ & $11.06^{\mathrm{a}} \pm 0.33$ & $12.63^{\mathrm{b}} \pm 0.60$ \\
\hline $\mathrm{b}^{*}[-]$ & $15.91^{\mathrm{a}} \pm 1.81$ & $16.71^{\mathrm{a}} \pm 1.33$ & $16.39^{\mathrm{a}} \pm 0.83$ & $19.31^{\mathrm{b}} \pm 0.93$ \\
\hline Hue angle $\left[{ }^{\circ}\right]$ & $0.98 \pm 0.05$ & $1.01 \pm 0.03$ & $0.98 \pm 0.03$ & $0.99 \pm 0.02$ \\
\hline Saturation index [\%] & $19.28^{\mathrm{a}} \pm 2.5$ & $19.75^{\mathrm{a}} \pm 1.68$ & $19.77^{\mathrm{a}} \pm 0.72$ & $23.08^{\mathrm{b}} \pm 1.01$ \\
\hline \multicolumn{5}{|c|}{ SAUSAGES } \\
\hline $\mathrm{H}[-]$ & $5.82 \pm 0.03$ & $5.87 \pm 0.06$ & $5.88 \pm 0.07$ & $5.85 \pm 0.02$ \\
\hline $\mathrm{L}^{*}[-]$ & $61.22^{\mathrm{b}} \pm 0.98$ & $58.85^{\mathrm{b}} \pm 0.48$ & $57.53^{\mathrm{a}} \pm 0.80$ & $57.23^{\mathrm{a}} \pm 0.65$ \\
\hline$a^{*}[-]$ & $12.06 \pm 0.59$ & $11.71 \pm 0.39$ & $11.87 \pm 0.44$ & $12.03 \pm 1.13$ \\
\hline $\mathrm{b}^{*}[-]$ & $7.69^{\mathrm{a}} \pm 1.07$ & $10.11^{\mathrm{b}} \pm 0.73$ & $12.00^{c} \pm 0.66$ & $11.94^{\mathrm{c}} \pm 0.68$ \\
\hline Hue angle $\left[{ }^{\circ}\right]$ & $0.57^{\mathrm{a}} \pm 0.07$ & $0.71^{\mathrm{b}} \pm 0.04$ & $0.79^{c} \pm 0.03$ & $0.78^{c} \pm 0.05$ \\
\hline Saturation index [\%] & $14.34^{\mathrm{a}} \pm 0.68$ & $15.48^{\mathrm{b}} \pm 0.61$ & $16.89^{c} \pm 0.62$ & $16.96^{\mathrm{c}} \pm 1.06$ \\
\hline
\end{tabular}

${ }^{1} \mathrm{C}$ - control group; $\mathrm{E}_{1}, \mathrm{E}_{2}, \mathrm{E}_{3}$ - groups, where bioactive components were used $\left(\mathrm{E}_{2}=1.5 \times \mathrm{E}_{1}, \mathrm{E}_{3}=2 \times \mathrm{E}_{1}\right)$; different letters within a row are significantly different ( $\left.\mathrm{p}<0.05\right)$.

Table 3. Textural properties of analyzed sausages.

\begin{tabular}{lccrc}
\hline \multirow{2}{*}{ PARAMETERS } & \multicolumn{3}{c}{ GROUP } \\
\cline { 2 - 5 } & $\mathrm{C}^{\mathbf{1}}$ & $\mathbf{E}_{1}$ & $\mathbf{E}_{2}$ & $\mathbf{E}_{3}$ \\
\hline Hardness [N] & $89.26 \pm 6.57$ & $81.58 \pm 6.37$ & $88.13 \pm 7.51$ & $91.29 \pm 10.05$ \\
Springiness [-] & $0.719 \pm 0.061$ & $0.705 \pm 0.055$ & $0.685 \pm 0.039$ & $0.674 \pm 0.057$ \\
Cohesiveness [-] & $0.498 \pm 0.058$ & $0.442 \pm 0.031$ & $0.439 \pm 0.055$ & $0.456 \pm 0.511$ \\
Adhesiveness [J/cm ${ }^{2}$ ] & $-0.157 \pm 0.020$ & $-0.122 \pm 0.014$ & $-0.125 \pm 0.022$ & $-0.135 \pm 0.028$ \\
Chewiness [N] & $0.498 \pm 0.058$ & $0.442 \pm 0.031$ & $0.439 \pm 0.055$ & $0.456 \pm 0.051$ \\
\hline
\end{tabular}

${ }^{1} \mathrm{C}$ - control group; $\mathrm{E}_{1}, \mathrm{E}_{2}, \mathrm{E}_{3}$ - groups, where bioactive components were used $\left(\mathrm{E}_{2}=1.5 \times \mathrm{E}_{1}, \mathrm{E}_{3}=2 \times \mathrm{E}_{1}\right)$.

Table 4. Chemical parameters of analyzed meat batters and sausages.

\begin{tabular}{|c|c|c|c|c|}
\hline \multirow{2}{*}{ PARAMETERS } & \multicolumn{4}{|c|}{ GROUP } \\
\hline & $\mathrm{C}^{1}$ & $\mathrm{E}_{1}$ & $\mathrm{E}_{2}$ & $\mathrm{E}_{3}$ \\
\hline \multicolumn{5}{|c|}{ SAUSAGE MEAT BATTERS } \\
\hline Total phenolic content $[\mathrm{mg}$ GAE/100 g] & $12.40^{\mathrm{a} 1} \pm 0.99$ & $22.19^{\mathrm{b}} \pm 0.88$ & $23.93^{\mathrm{bc}} \pm 0.61$ & $25.69^{\mathrm{c}} \pm 0.84$ \\
\hline Total antioxidant activity [\%] & $32.53^{\mathrm{a}} \pm 0.27$ & $76.85^{\mathrm{b}} \pm 0.13$ & $85.14^{\mathrm{c}} \pm 0.12$ & $85.70^{\mathrm{d}} \pm 0.19$ \\
\hline Ant-inflamantory activity [\%] & $0.27^{\mathrm{a}} \pm 0.03$ & $0.91^{\mathrm{b}} \pm 0.07$ & $2.42^{c} \pm 0.19$ & $2.63^{\mathrm{c}} \pm 0.16$ \\
\hline \multicolumn{5}{|c|}{ SAUSAGES } \\
\hline Total phenolic content [mg GAE/100 g] & $15.69^{\mathrm{a}} \pm 0.78$ & $27.51^{\mathrm{b}} \pm 1.58$ & $29.68^{\mathrm{bc}} \pm 0.93$ & $31.84^{\mathrm{c}} \pm 0.51$ \\
\hline Total antioxidant activity [\%] & $46.88^{\mathrm{a}} \pm 0.11$ & $86.58^{\mathrm{b}} \pm 0.57$ & $86.98^{\mathrm{bc}} \pm 0.38$ & $87.57^{c} \pm 0.09$ \\
\hline Ant-inflamantory activity [\% ] & $0.09^{\mathrm{a}} \pm 0.02$ & $0.77^{\mathrm{b}} \pm 0.15$ & $0.99^{\mathrm{bc}} \pm 0.14$ & $1.30^{\complement} \pm 0.13$ \\
\hline
\end{tabular}

${ }^{1} \mathrm{C}$ - control group; $\mathrm{E}_{1}, \mathrm{E}_{2}, \mathrm{E}_{3}$ - groups, where bioactive components were used $\left(\mathrm{E}_{2}=1.5 \times \mathrm{E}_{1}, \mathrm{E}_{3}=2 \times \mathrm{E}_{1}\right)$; different letters within a row are significantly different $(\mathrm{p}<0.05)$. 
Półtorak et al.

Table 5. The semi-consumer scaling method of sensory evaluation of analyzed sausages.

\begin{tabular}{lcrcc}
\hline \multirow{2}{*}{ SENSORY ATRIBUTES } & \multicolumn{3}{c}{ GROUP } \\
\cline { 2 - 5 } & \multicolumn{1}{c}{$\mathrm{C}^{1}$} & $\mathrm{E}_{1}$ & $\mathrm{E}_{2}$ & $5.68 \pm 2.24$ \\
COLOR & $6.73 \pm 2.07$ & $6.26 \pm 1.91$ & $6.63 \pm 2.36$ & $5.71 \pm 2.29$ \\
ODOR & $7.34 \pm 1.87$ & $7.23 \pm 1.76$ & $2.78 \pm 2.71$ & $6.26 \pm 2.08$ \\
FOREIGN ODOR & $1.90 \pm 2.10$ & $2.12 \pm 2.69$ & $4.68^{\mathrm{a}} \pm 2.66$ & $2.64 \pm 2.53$ \\
TASTE & $6.45^{\mathrm{b}} \pm 2.24$ & $5.95^{\mathrm{a}} \pm 2.41$ & $3.46^{\mathrm{b}} \pm 2.71$ & $5.09^{\mathrm{a}} \pm 2.14$ \\
FOREIGN TASTE & $1.65^{\mathrm{a} \pm 1.91}$ & $2.78^{\mathrm{ab}} \pm 2.52$ & $5.51 \pm 2.22$ & $3.56^{\mathrm{b}} \pm 2.85$ \\
JUICINES & $6.03 \pm 2.41$ & $5.80 \pm 2.17$ & $6.00 \pm 2.32$ & $4.90 \pm 2.00$ \\
CONSISTENCY & $6.76 \pm 2.36$ & $6.83 \pm 2.15$ & $4.33^{\mathrm{a}} \pm 2.39$ & $6.01 \pm 2.42$ \\
FAT PERCEPTIBILITY & $6.46^{\mathrm{b} \pm 2.48}$ & $4.83^{\mathrm{a}} \pm 2.52$ & $5.37^{\mathrm{a}} \pm 2.43$ & $4.35^{\mathrm{a}} \pm 2.29$ \\
OVERALL ACCEPTABILITY & $6.86^{\mathrm{b} \pm 2.08}$ & $6.23^{\mathrm{ab}} \pm 1.92$ & $5.70^{\mathrm{ab}} \pm 2.25$ \\
\hline
\end{tabular}

${ }^{1} \mathrm{C}$ - control group; $\mathrm{E}_{1}, \mathrm{E}_{2}, \mathrm{E}_{3}$ - groups, where bioactive components were used $\left(\mathrm{E}_{2}=1.5 \times \mathrm{E}_{1}, \mathrm{E}_{3}=2 \times \mathrm{E}_{1}\right)$; different letters within a row are significantly different ( $\left.\mathrm{p}<0.05\right)$.

isothiocyanates present in maca (Sandoval et al., 2002) or the monophenolics and vitamin $\mathrm{C}$ present in honey (Schramm et al., 2003) have been shown to have antioxidant activities. Also in our study, the relationships between phenolic content $(\mathrm{Y})$ and total antioxidant activity $(\mathrm{X})$ of meat batters $\left(\mathrm{r}^{2}=0.98\right.$, $\mathrm{Y}=0.23273 \mathrm{X}+4.7501)$, as well as finished products $\left(\mathrm{r}^{2}=0.96\right.$, $\mathrm{Y}=0.34935 \mathrm{X}-0.7209$ ) showed a positive high correlation. The obtained data indicate that the TAA in examined groups were contributed mainly by phenolic compounds contained in the used components, and their redox properties (Zheng \& Wang, 2001). Additionally, the data are in agreement with the report of Tangkanakul et al. (2009), who showed that natural antioxidants retained their activity after the thermal processing of food.

According to Table 4, the used ingredients improved the anti-inflammatory activity of meat batters and finished products $(p<0.05)$. When the highest levels of bioactive components were used, the increases compared to the control groups were almost tenfold and fifteenfold respectively. It is suggested that the antioxidant content of products can determine their anti-inflammatory activity, since the formation of free radicals and destruction can be inhibited by antioxidants. It is also believed that, among others, honey owes its anti-inflammatory properties to the ability to inhibit feedback leading to inflammation caused by hydrogen peroxide (Bashkaran et al., 2011; Kassim et al., 2010).

\subsection{Consumer evaluation}

The sensory traits of experimental sausages are presented in Table 5. The addition of experimental components up to $4.60 \%$ did not affect consumers' assessment of sausage colour, odour, juiciness and consistency. There were also no significant differences $(p \geq 0.05)$ in taste, fat perceptibility and overall acceptability between groups with different levels of bioactive components $\left(\mathrm{E}_{1}, \mathrm{E}_{2}, \mathrm{E}_{3}\right)$; however, some differences in relation to the control group $(\mathrm{C})$ were identified.

Although fat was the most noW celu ticeable in control sausages $(\mathrm{p}<0.05)$, they were characterized by better taste and overall acceptability. This is probably due to the fact that fat in meat products is thought to be a flavour-carrier, which delivers taste and odour compounds in certain foods (Mendoza et al., 2001). Additionally, the slightly lower acceptability of experimental sausages could be related to the taste of additives that are not specific to this type of product, although Mohammed (2006) reported that the addition of up to $7.5 \%$ bee honey to beef sausages had a positive effect on their sensory acceptability. The application of other ingredients such as catuaba, galangal, roseroot, maca root and guarana at higher levels might be limited. Despite this fact, the assessments of the groups where the experimental components mixture was used up to $4.60 \%$ in relation to the cured meat were at a relatively high level, oscillating around 6 .

\section{Conclusion}

Based on the obtained results, sausages with $1.734 \%$ of catuaba bark, $0.022 \%$ of ground great galangal root, $0.458 \%$ of ground roseroot, $0.614 \%$ of maca root extract (4:1), $0.600 \%$ of ground guarana and $1.146 \%$ of polyfloral honey were characterized not only by good sensorial acceptability, but also by the best antioxidant and anti-inflamantory properties. Additionally, their regular intake could prevent other maladies typical in men; however, this requires further research.

\section{Acknowledgements}

Research financed by Polish Ministry of Science and Higher Education within funds of Faculty of Human Nutrition and Consumer Sciences, Warsaw University of Life Science (WULS), for scientific research.

\section{References}

Adamczyk, A., Buchwald, W., \& Gryszczyńska, A. (2016). Biometric features and content of phenolic compounds of roseroot (Rhodiola rosea L.). Acta Societatis Botanicorum Poloniae, 85(3), 1-10.

Artés, F., Minguez, M. I., \& Hornero, D. (2002) Analysing changes in fruit pigments. In D. B. McDougall (Eds.), Colour in food (pp. 248282). Cambridge: Woodhead Publishing. http://dx.doi.org/10.153 3/9781855736672.2.248.

Barbosa, N. R., Fischmann, L., Talib, L. L., \& Gattaz, W. F. (2004). Inhibition of platelet phospholipase A2 activity by catuaba extract suggests antiinflammatory properties. Phytotherapy Research, 18(11), 942-944. http://dx.doi.org/10.1002/ptr.1579. PMid:15597313.

Barrett-Connor, E., Von Muhlen, D. G., \& Kritz-Silverstein, D. (1999). Bioavailable testosterone and depressed mood in older men: the Rancho Bernardo study. The Journal of Clinical Endocrinology and 
Metabolism, 84(2), 573-577. http://dx.doi.org/10.1210/jcem.84.2.5495. PMid:10022418.

Bashkaran, K., Zunaina, E., Bakiah, S., Sulaiman, S. A., Sirajudeen, K. N. S., \& Naik, V. (2011). Anti-inflammatory and antioxidant effects of Tualang honey in alkali injury on the eyes of rabbits: Experimental animal study. Complementary and Alternative Medicine, 11(90), 1-11. PMid:21982267.

Basile, A., Ferrara, L., Pezzo, M. D., Mele, G., Sorbo, S., Bassi, P., \& Montesano, D. (2005). Antibacterial and antioxidant activities of ethanol extract from Paullinia cupana Mart. Journal of Ethnopharmacology, 102(1), 32-36. http://dx.doi.org/10.1016/j.jep.2005.05.038. PMid:16040216.

Bhat, Z. F., \& Bhat, H. (2011). Functional meat products: a review. International Journal of Meat Science, 1(1), 1-14. http://dx.doi. org/10.3923/ijmeat.2011.1.14.

Brighente, I. M. C., Dias, M., Verdi, L. G., \& Pizzolatti, M. G. (2007). Antioxidant activity and total phenolic content of some Brazilian species. Pharmaceutical Biology, 45(2), 156-161. http://dx.doi. org/10.1080/13880200601113131.

Campos, M. M., Fernandes, E. S., Ferreira, J., Santos, A. R., \& Calixto, J. (2005). Antidepressant-like effects of Trichilia catigua (Catuaba) extract: evidence for dopaminergic-mediated mechanisms. Psychopharmacology, 182(1), 45-53. http://dx.doi.org/10.1007/ s00213-005-0052-1. PMid:15991001.

Cao, L. L., Du, G. H., \& Wang, M. W. (2006). The effect of salidroside on cell damage induced by glutamate and intracellular free calcium in PC12 cells. Journal of Asian Natural Products Research, 8(1-2), 159-165. http://dx.doi.org/10.1080/1028602042000325645. PMid:16753799.

Chassot, J. M., Longhini, R., Gazarini, L., Mello, J. C., \& Oliveira, R. M. (2011). Preclinical evaluation of Trichilia catigua extracts on the central nervous system of mice. Journal of Ethnopharmacology, 137(3), 1143-1148. http://dx.doi.org/10.1016/j.jep.2011.07.032. PMid:21801825.

Cheah, P. B., \& Abu-Hasim, N. H. (2000). Natural antioxidant extract from galangal (Alpinia galanga) for minced beef. Journal of the Science of Food and Agriculture, 80(10), 1565-1571. http://dx.doi. org/10.1002/1097-0010(200008)80:10<1565::AID-JSFA677>3.0.CO;2-7.

Chen, X., Liu, J., Gu, X., \& Ding, F. (2008). Salidroside attenuates glutamate-induced apoptotic cell death in primary cultured hippocampal neurons of rats. Brain Research, 1238, 189-198. http:// dx.doi.org/10.1016/j.brainres.2008.07.051. PMid:18680733.

Feldman, H. A., Longcope, C., Derby, C. A., Johannes, C. B., Araujo, A. B., Coviello, A. D., Bremner, W. J., \& McKinlay, J. B. (2002). Age trends in the level of serum testosterone and other hormnes in middle-aged men: longitudinal results from Massachusetts Male Aging Study. The Journal of Clinical Endocrinology and Metabolism, 87(2), 589-598. http://dx.doi.org/10.1210/jcem.87.2.8201. PMid:11836290.

Ford, A. H., Yeap, B. B., Flicker, L., Hankey, G. J., Chubb, S. A., Handelsman, D. J., Golledge, J., \& Almeida, O. P. (2016). Prospective longitudinal study of testosterone and incident depression in older men: the health in men study. Psychoneuroendocrinology, 64, 57-65. http://dx.doi.org/10.1016/j.psyneuen.2015.11.012. PMid:26615472.

Giltay, E. J., Enter, D., Zitman, F. G., Penninx, B. W. J. H., Van Pelt, J., Spinhoven, P., \& Roelofs, K. (2012). Salivary testosterone: Associations with depression, anxiety disorders, and antidepressant use in a large cohort study. Journal of Psychosomatic Research, 72(3), 205-213. http://dx.doi.org/10.1016/j.jpsychores.2011.11.014. PMid:22325700.

Gomuła, A., \& Rabijewski, M. (2010). Testosterone deficiency syndrome - diagnosis and treatment - based on age-related testosterone referent levels. Polish Sexology, 8(1), 1-16.

Heo, M. Y., Sohn, S. J., \& Au, W. W. (2001). Anti-genotoxicity of galangin as a cancer chemopreventive agent candidate. Mutation Research,
488(2), 135-150. http://dx.doi.org/10.1016/S1383-5742(01)00054-0. PMid:11344041.

Huhtaniemi, I. T. (2014). Andropause: lessons from the European Male Ageing Study. Annales d'Endocrinologie, 75(2), 128-131. http://dx.doi. org/10.1016/j.ando.2014.03.005. PMid:24793989.

International Organization for Standardization - ISO. (2002). ISO 2917:2001/Ap1:2002: Meat and meat products - Measurement of pH - Reference method. Warsaw: Polish Committee for Standardization.

Kamdem, J. P., Olalekan, E. O., Hassan, W., Kade, I. J., Yetunde, O., Boligon, A. A., Athayde, M. L., Souza, D. O., \& Rocha, J. B. T. (2013). Trichilia catigua (Catuaba) bark extract exerts neuroprotection against oxidative stress induced by different neurotoxic agents in rat hippocampal slices. Industrial Crops and Products, 50, 625-632. http://dx.doi.org/10.1016/j.indcrop.2013.07.033.

Kassim, M., Achoui, M., Mustafa, M. R., Mohd, M. A., \& Yusoff, K. M. (2010). Ellagic acid, phenolic acids, and flavonoids in Malaysian honey extracts demonstrate in vitro anti-inflammatory activity. Nutrition Research (New York, N.Y.), 30(9), 650-659. http://dx.doi. org/10.1016/j.nutres.2010.08.008. PMid:20934607.

Kenani, M., Rajabzadeh, A., Saki, G., Khodadadi, A., Sarkaki, A., Jafai, A., \& Hemadi, M. (2015). A survey of the relationship between noised pollution, honey and vitamin $\mathrm{E}$ and plasma level of blood sexual hormones in noise-exposed rats. Journal of Health Research, 6(1), 1-5.

Lee, M. S., Lee, H. W., You, S., \& Ha, K.-T. (2016). The use of maca (Lepidium meyenii) to improve semen quality: A systematic review. Maturitas, 92, 64-69. http://dx.doi.org/10.1016/j.maturitas.2016.07.013. PMid:27621241.

Majewska, A., Grażyna, H., Mirosława, F., Natalia, U., Agnieszka, P., Alicja, Z., \& Kuraś, M. (2006). Antiproliferative and antimitotic effect, $S$ phase accumulation and induction of apoptosis and necrosis after treatment of extract from Rhodiola rosea rhizomes on HL-60 cells. Journal of Ethnopharmacology, 103(1), 43-52. http://dx.doi. org/10.1016/j.jep.2005.05.051. PMid:16169692.

Majhenič, L., Škerget, M., \& Knez, Ž. (2007). Antioxidant and antimicrobial activity of guarana seed extracts. Food Chemistry, 104(3), 1258-1268. http://dx.doi.org/10.1016/j.foodchem.2007.01.074.

McHenry, J., Carrier, N., Hull, E., \& Kabbaj, M. (2014). Sex differences in anxiety and depression: Role of testosterone. Frontiers in Neuroendocrinology, 35(1), 42-57. http://dx.doi.org/10.1016/j. yfrne.2013.09.001. PMid:24076484.

Melnikovova, I., Fait, T., Kolarova, M., Fernandez, E. C., \& Milella, L. (2015). Effect of Lepidium meyenii Walp. on Semen Parameters and Serum Hormone Levels in Healthy Adult Men: A Double-Blind, Randomized, Placebo-Controlled Pilot Study. Evidence-Based Complementary and Alternative Medicine, 2015, 1-6. http://dx.doi. org/10.1155/2015/324369. PMid:26421049.

Mendoza, E., Garcia, M. L., Casas, C., \& Selgas, M. D. (2001). Inulin as fat substitute in low fat, dry fermented sausages. Meat Science, 57(4), 387-393. http://dx.doi.org/10.1016/S0309-1740(00)00116-9. PMid:22061711.

Meo, S. A., Al-Asiri, S. A., Mahesar, A. L., \& Ansari, M. J. (2017). Role of honey in modern medicine. Saudi Journal of Biological Sciences, 24(5), 975-1104. http://dx.doi.org/10.1016/j.sjbs.2016.12.010. PMid:28663690.

Mohammed, R. A. (2006). Quality evaluation of beef sausage incorporated with bee honey (Master Thesis). University of Khartoum, Sudan.

Mouser, J. G., Loprinzi, P. D., \& Loenneke, J. P. (2016). The association between physiologic testosterone levels, lean mass, and fat mass in a nationally representative sample of men in the United States. Steroids, 115, 62-66. http://dx.doi.org/10.1016/j.steroids.2016.08.009. PMid:27543675. 
Oryan, A., Alemzadeh, E., \& Moshiri, A. (2016). Biological properties and therapeutic activities of honey in wound healing: A narrative review and meta-analysis. Journal of Tissue Viability, 25(2), 98-118. http://dx.doi.org/10.1016/j.jtv.2015.12.002. PMid:26852154.

Osés, S. M., Pascual-Maté, A., Fernández-Muiño, M. A., López-Díaz, T. M., \& Sancho, M. T. (2016). Bioactive properties of honey with propolis. Food Chemistry, 196, 1215-1223. http://dx.doi.org/10.1016/j. foodchem.2015.10.050. PMid:26593609.

Pino-Figueroa, A., Nguyen, D., \& Maher, T. J. (2010). Neuroprotective effects of Lepidium meyenii (Maca). Annals of the New York Academy of Sciences, 1199(1), 77-85. http://dx.doi.org/10.1111/j.17496632.2009.05174.x. PMid:20633111.

Pizzolatti, M. G., Venson, A. F., Smânia, A. J., Smâni, E. F. A., \& BrazFilho, R. (2002). Two epimeric flavalignans from Trichilia catigua (Meliaceae) with antimicrobial activity. Zeitschrift für Naturforschung, 57(5-6), 483-488.

Pyrzynska, K., \& Biesaga, M. (2009). Analysis of phenolic acids and flavonoids in honey. TrAC Trends in Analytical Chemistry, 28(7), 893-902. http://dx.doi.org/10.1016/j.trac.2009.03.015.

Quadri, S. A., Qadri, A. N., Hahn, M. E., Mann, K. K., \& Sherr, D. H. (2000). The Bioflavonoid galangin blocks aryl hydrocarbon receptor activation and polycyclic aromatic hydrocarbon induced pre-B cell apoptosis. Molecular Pharmacology, 58(3), 515-525. http://dx.doi. org/10.1124/mol.58.3.515. PMid:10953044.

Rajabzadeh, A., Sagha, M., Gholami, M. R., \& Hemmati, R. (2015). Honey and vitamin E restore the plasma level of gonadal hormones and improve the fertilization capacity in noise-stressed rats. Crescent Journal of Medical and Biological Sciences, 2(2), 64-68.

Rao, P. V., Krishnan, K. T., Salleh, N., \& Gan, S. H. (2016). Biological and therapeutic effects of honey produced by honey bees and stingless bees: a comparative review. Revista Brasileira de Farmacognosia, 26(5), 657-664. http://dx.doi.org/10.1016/j.bjp.2016.01.012.

Rashad, U. M., Al-Gezawy, S. M., El-Gezawy, E., \& Azzaz, A. N. (2009). Honey as topical prophylaxis against radiochemotherapy-induced mucositis in head and neck cancer. The Journal of Laryngology and Otology, 123(2), 223-228. http://dx.doi.org/10.1017/S0022215108002478. PMid:18485252.

Ravindran, P. N., Pillai, G. S., Balachandran, I., \& Divakaran, M. (2012) Galangal. In K. V. Peter (Eds.), Handbook of herbs and spices (2nd ed., pp. 303-318). Cambridge: Woodhead Publishing. http://dx.doi. org/10.1533/9780857095688.303.

Rhoden, E. L., \& Morgentaler, A. (2004). Risks of testosterone-replacement therapy and recommendations for monitoring. The New England Journal of Medicine, 350(5), 482-492. http://dx.doi.org/10.1056/ NEJMra022251. PMid:14749457.

Rice-Evans, C. A., Miller, N., \& Paganga, G. (1996). Structure-antioxidant activity relationships of flavonoids and phenolic acids. Free Radical Biology \& Medicine, 20(7), 933-956. http://dx.doi.org/10.1016/08915849(95)02227-9. PMid:8743980.

Sánchez-Moreno, C., Larrauri, J. A., \& Saura-Calixto, F. (1998). A procedure to measure the antiradical efficiency of polyphenols. Journal of the Science of Food and Agriculture, 76(2), 270-276. http://dx.doi.org/10.1002/(SICI)1097-0010(199802)76:2<270::AIDJSFA945>3.0.CO;2-9.

Sandoval, M., Okuhama, N. N., Angeles, F. M., Melchor, V. V., Condezo, L. A., Lao, J., \& Miller, M. J. S. (2002). Antioxidant activity of the cruciferous vegetable Maca (Lepidium meyenii). Food Chemistry, 79(2), 207-213. http://dx.doi.org/10.1016/S0308-8146(02)00133-4.

Schramm, D. D., Karim, M., Schrader, H. R., Holt, R. R., Cardetti, M., \& Keen, C. L. (2003). Honey with high levels of antioxidants can provide protection to healthy human subjects. Journal of Agricultural and Food Chemistry, 51(6), 1732-1735. http://dx.doi.org/10.1021/ jf025928k. PMid:12617614.

Sebranek, J. G., Sewalt, V. J. H., Robbins, K. L., \& Houser, T. A. (2005). Comparison of natural rosemary extract and $\mathrm{BHA} / \mathrm{BHT}$ for relative antioxidant effectiveness in pork sausage. Meat Science, 69(2), 289296. http://dx.doi.org/10.1016/j.meatsci.2004.07.010. PMid:22062821.

Singleton, V. L., \& Rossi, J. A. (1965). Colorimetry of total phenolics with phosphomolybdic and phosphotungstic acid reagents. American Journal of Enology and Viticulture, 16, 144-147.

Tang, W., Hioki, H., Harada, K., Kubo, M., \& Fukuyama, Y. (2007). Antioxidant phenylpropanoid-substituted epicatechins from Trichilia catigua. Journal of Natural Products, 70(12), 2010-2013. http://dx.doi. org/10.1021/np0703895. PMid:18020420.

Tang, W., Jin, L., Xie, L., Huang, J., Wang, N., Chu, B., Dai, X., Liu, Y., Wang, R., \& Zhang, Y. (2017). Structural Characterization and Antifatigue Effect In Vivo of Maca (Lepidium meyenii Walp) Polysaccharide. Journal of Food Science, 82(3), 757-764. http://dx.doi. org/10.1111/1750-3841.13619. PMid:28231388.

Tangkanakul, P., Auttaviboonkul, P., Niyomwit, B., Lowvitoon, N., Charoenthamawat, P., \& Trakoontivakorn, G. (2009). Antioxidant capacity, total phenolic content and nutritional composition of Asian foods after thermal processing. International Food Research Journal, 16, 571-580.

Thomas, R., Anjaneyulu, A. S. R., Mendiratta, S. K., \& Kondaiah, N. (2008). Effect of Humectants on the quality of pork sausages. American Journal of Food Technology, 3(2), 56-67. http://dx.doi. org/10.3923/ajft.2008.56.67.

Viana, A. F., Maciel, I. S., Motta, E. M., Leal, P. C., Pianowski, L., Campos, M. M., \& Calixto, J. B. (2011). Antinociceptive activity of Trichilia catigua hydroalcoholic extract: new evidence on its dopaminergic effects. Evidence-Based Complementary and Alternative Medicine, 2011, 1-8. http://dx.doi.org/10.1093/ecam/nep144. PMid:19815648.

Wagh, R. V., Chatli, M. K., Ruusunen, M., Puolanne, E., \& Ertbjerg, P. (2015). Effect of various phyo-extracts on physico-chemical, colour, and oxidative stability of pork Frankfurters. Asian-Australasian journal of animal sciences, 28(8), 1178-1186. http://dx.doi.org/10.5713/ ajas.14.0752. PMid:26104527.

Wal, P., \& Wal, A. (2013). An Overview of adaptogens with a special emphasis on Withania and Rhodiola. In B. Debasis, N. Sreejayan, \& K. S. Chandan (Eds.), Nutrition and enhanced sports performance. muscle building, endurance, and strength (pp. 343-350). London: Academic Press. http://dx.doi.org/10.1016/B978-0-12-396454-0.00034-5.

Wang, C., Nieschlag, E., Swerdloff, R. S., Behre, H., Hellstrom, W. J., Gooren, L. J., Kaufman, J. M., Legros, J. J., Lunenfeld, B., Morales, A., Morley, J. E., Schulman, C., Thompson, I. M., Weidner, W., \& Wu, F. C. (2009). ISA, ISSAM, EAU, EAA and ASA recommendations: investigation, treatment and monitoring of late-onset hypogonadism in males. The Aging Male, 12(1), 5-12. http://dx.doi.org/10.1080/13685530802389628. PMid:18763169.

Westley, C. J., Amdur, R. L., \& Irwig, M. S. (2015). High rates of depression and depressive symptoms among men referred for borderline testosterone levels. Journal of Sexual Medicine, 12(8), 1753-1760. http://dx.doi.org/10.1111/jsm.12937. PMid:26129722.

Wyrwisz, J., Półtorak, A., Zalewska, M., Zaremba, R., \& Wierzbicka, A. (2012). Analysis of relationship between basic composition, $\mathrm{pH}$, and physical properties of selected bovine muscles. Bulletin of the Veterinary Institute in Pulawy, 56(3), 403-409. http://dx.doi. org/10.2478/v10213-012-0071-8.

Zheng, W., \& Wang, S. Y. (2001). Atioxidant activity and phenolic compounds in selected herbs. Journal of Agricultural and Food Chemistry, 49(11), 5165-5170. http://dx.doi.org/10.1021/jf010697n. PMid:11714298. 